Jurnal Ilmiah Ibnu Sina, 6(2), Oktober 2021, 206-214

p-ISSN: 2502-647X; e-ISSN: 2503-1902

\title{
METODE INTERPRETATIVE PHENOMENOLOGICAL ANALYSIS (IPA): PERSEPSI TENAGA KESEHATAN DAN PASIEN TERHADAP PENGOBATAN ASMA
}

\author{
Marthy Meliana Ariyanti Jalmav ${ }^{1,2}$, Amelia Lorensia ${ }^{3 *}$, Ananta Yudiarso ${ }^{4}$, \\ Daniel Maranatha ${ }^{5}$ \\ ${ }^{1}$ Postgraduate Student of Master of Pharmacy Science, Faculty of Pharmacy, \\ Universitas Anwar Medika, Sidoarjo \\ ${ }^{2}$ Postgraduate Student of Master of Pharmacy Science, Faculty of Pharmacy, \\ Surabaya of University, Surabaya \\ ${ }^{3}$ Departement of Clinical-Community Pharmacy, Faculty of Pharmacy, Surabaya \\ of University, Surabaya \\ ${ }^{4}$ Departement of Social Psychology, Faculty of Phsychology, Surabaya of \\ University, Surabaya \\ ${ }^{5}$ Department of Pulmonology and Respiratory Medicine, Faculty of Medicine, \\ University of Airlangga, General Hospital Dr. Soetomo, Surabaya \\ *Email ${ }^{1,2}$ : marthymelianaj@gmail.com \\ Email³: amelia.lorensia@gmail.com; amelia.lorensia@staff.ubaya.ac.id \\ Email ${ }^{4}$ ananta@staff.ubaya.ac.id \\ Email ${ }^{5}$ : dmaranatha@hotmail.com
}

Artikel diterima: 29 April 2021; Disetujui: 06 Oktober 2021

DOI: https://doi.org/10.36387/jiis.v6i2.691

\begin{abstract}
ABSTRAK
Pelayanan kefarmasian oleh apoteker dalam penatalaksanaan asma memiliki peranan yang penting yaitu pemantauan pengobatan. Pengobatan asma yang optimal bagi pasien membutuhkan kerjasama antara pasien, tenaga kesehatan, yang melibatkan dokter, dan apoteker. Oleh karena itu tujuan penelitian ini adalah mengetahui persepsi tenaga kesehatan dan pasien tentang pengobatan asma dan pelayanan kefarmasian pada menejemen asma. Metode penelitian ini berdasarkan perspektif fenomenologis dengan interpretative phenomenological analysis (IPA) pada dokter spesialis penyakit paru, pasien asma rawat jalan, farmasis dan perawat yang berhubungan langsung dengan pengobatan penyakit asma di suatu rumah sakit di Surabaya yang dilakukan selama dua tahun dengan menggunakan purposive sampling. Analisis pada data yang diperoleh dari hasil wawancara dengan 10 orang sebagai responden (4 dokter, 2 farmasis dan 4 pasien). Hasil penelitian ini menunjukkan bahwa pasien asma mengetahui cara memanajemen asma dan menggunakan obat asma dengan baik. Selain itu diketahui bahwa pasien asma merasakan peran dokter dalam pengobatan asma sangat mendominasi; dokter dan perawat merasakan peran farmasis hanya sebatas penyerahan obat saja; dan farmasis menganggap bahwa perannya selama ini sudah dilakukan dengan baik meskipun tidak seluruh pasien mendapatkan edukasi pengobatan asma yang sama. Oleh karena itu diperlukan evaluasi terhadap peran farmasis dalam melakukan perannya pada pengobatan asma ini agar terjadi kolaborasi yang lebih harmonis.
\end{abstract}


Jurnal Ilmiah Ibnu Sina, 6(2), Oktober 2021, 206-214

p-ISSN: 2502-647X; e-ISSN: 2503-1902

Kata Kunci: persepsi, asma, perawatan kesehatan, kefarmasian

\begin{abstract}
Pharmaceutical care by pharmacists in the management have an important role of treatment monitoring. Optimal asthma treatment for patients requires cooperation between patients, healthcares, involving doctors, nurses, and pharmacists. Therefore the purpose of this study is to know the perception of healthcares and patients about asthma treatment and pharmaceutical cares on asthma mangement. The method of this study is based on phenomenological perspective with interpretative phenomenological analysis (IPA) on pulmonologist, outpatient asthma, pharmacist and nurse who directly correlated with asthma treatment at a hospital in Surabaya conducted for two years using purposive sampling. Analysis of the data obtained from interviews with 10 people as respondents (4 doctors, 2 pharmacists and 4 patients). The results of this study indicate that asthma patients know how to manage asthma and use asthma drugs well. In addition it is known that asthma patients feel the role of doctors in the treatment of asthma is very dominating; pulmonologists and nurses perceive that the role of pharmacists is limited to drug delivery; and pharmacists assume that their role has been well done although not all patients get the same asthma treatment education. It is therefore necessary to evaluate the role of pharmacist in performing its role in the treatment of this asthma in order for a more harmonious collaboration.
\end{abstract}

Keywords: perception, asthma, healthcare, pharmaceutical care

\section{PENDAHULUAN}

Asma adalah penyakit heterogen yang ditandai inflamasi kronis pada saluran napas dengan gejala berupa mengi, napas yang pendek, dada terasa sesak dan/atau batuk (Global Initiative for Asthma, 2020; Quirt et al., 2018). Pengobatan asma merupakan pengobatan jangka panjang yang membutuhkan kepatuhan tinggi dari pasien (George \& Bender, 2019). Oleh karena itu kolaborasi tenaga kesehatan dengan keahliannya masing-masing dapat memberikan peningkatan signifikan terhadap kesembuhan pasien (Reeves et al., 2017). Secara umum, dokter mendiagnosis dan meresepkan kemudian farmasis/apoteker yang menyediakan dan memberikan obat (Dalton \& Byrne, 2017).

Pemahaman tentang persepsi pasien secara esensial dapat dikarenakan pasien asma cenderung mendeskripsikan pengobatan asma terhadap aktivitas kehidupan mereka sehari-hari dan persepsi pasien terhadap gejala asma menentukan pula 
Jurnal Ilmiah Ibnu Sina, 6(2), Oktober 2021, 206-214

p-ISSN: 2502-647X; e-ISSN: 2503-1902

aspek-aspek lainnya dalam perilaku penyakit asma yang dilakukan oleh pasien (Miravitlles et al., 2013; Bidad et al., 2018).

Pengalaman, persepsi, dan penilaian dari tenaga kesehatan (termasuk apoteker) yang terlibat dalam perawatan yang diberikan oleh layanan kesehatan diidentifikasi, memungkinkan untuk menghasilkan informasi substantif tentang aspekaspek kunci, praktik, dan makna yang dikaitkan dengan perawatan kesehatan dari perspektif tersebut (Miravitlles et al., 2013; Bidad et al., 2018).

Penelitian sebelumnya yang telah ada lebih difokuskan pada persepsi pasien terhadap tingkat keparahan asma, atau persepsi dokter dan farmasis terhadap kesembuhan asma (Hannane et al., 2019; Kaptein et $a l .$, 2010). Oleh karena itu penelitian ini hendak mengetahui bagaimana persepsi dokter, pasien, dan farmasis terhadap pengobatan asma serta persepsi mereka terhadap peran farmasis dalam pengobatan asma.

\section{METODE PENELITIAN}

\section{$\underline{\text { Jenis dan Variabel Penelitian }}$}

Penelitian kualitatif ini dilakukan dengan menggunakan metode penelitian IPA untuk mengamati tentang pengalaman subyek, bagaimana subyek mengartikan suatu obyek dalam kehidupannya, dan hubungan antara kejadian/peristiwa (Smith \& Osborn, 2015). Dalam penelitian ini, yang menjadi fokus penelitian adalah cara pandang/sudut pandang/persepsi dari subyek penelitian untuk mewujudkan pengobatan asma sesuai dengan tujuan yang akan dicapai. Waktu penelitian ini dilakukan secara bertahap mulai dari Bulan Juni 2014-Januari 2016.

\section{Populasi dan Sampel Penelitian}

Populasi penelitian adalah dokter spesialis penyakit paru, pasien asma rawat jalan, dan farmasis yang berhubungan langsung dengan pengobatan penyakit asma di suatu RSUD di Surabaya. Responden (subjek penelitian) adalah bagian dari populasi yang bersedia diwawancara dan pada responden pasien berusia lebih dari 18 tahun, tidak mempunyai komplikasi penyakit saluran napas lain, tidak memiliki gangguan mental, dan tidak mempunyai masalah pada pendengaran serta berbicara.

Teknik sampling yang 
Jurnal Ilmiah Ibnu Sina, 6(2), Oktober 2021, 206-214

p-ISSN: 2502-647X; e-ISSN: 2503-1902

digunakan dalam penelitian ini adalah purposive sampling. Prinsip dasar sampling dalam penelitian kualitatif adalah saturasi data, yaitu sampling sampai pada suatu titik kejenuhan dimana tidak ada informasi baru yang didapat dari pengalaman telah dicapai.

\section{Pengumpulan dan Analisis Data}

Pengambilan data menggunakan metode indepth interview hingga data mencapai saturasi. Proses analisa data dimulai dari open coding, axial coding sampai selective coding. Dan pada tahap open coding dilakukan pentraskripan hasil wawancara secara verbatim yang menggambarkan proses wawancara, refleksi penelitian terhadap hasil wawancara (self reflection).

\section{HASIL DAN PEMBAHASAN}

Analisis deskriptif data penelitian adalah analisis pada data hasil wawancara responden yang terdiri dari 4 orang dokter sebagai tenaga medis, 2 orang farmasis dan 4 orang pasien rawat jalan.

\section{Persepsi Dokter Spesialis Paru terhadap Pengobatan Asma}

a. Peran apoteker dalam pengobatan asma sangat perlu namun karena keterbatasan waktu maka sulit untuk apoteker menjalankan perannya dengan baik.

b. Peran apoteker dalam mengedukasi pasien tentang cara penggunaan obat sangat diperlukan untuk menjawab kebingungan dari pasien.

c. Perlu adanya penyesuaian dalam pemberian dosis obat ke pasien berdasarkan riwayat penyakit pasien (patient medication record).

d. Monitoring obat selama ini dilakukan oleh dokter yang memiliki peran untuk mengecek kondisi pasien dan juga peran pasien yang aktif dalam bertanya.

e. Kurang tampaknya peran apoteker pada tenaga medis yang lain.

Tujuan atau fokus dalam pengobatan asma ini adalah tingkat kontrol asma pada pasien, dan pengobatan asma yang baik seharusnya gejala hilang dan fungsi paru yang normal menjadi outcome yang diinginkan dalam pengobatan asma pada pasien. Persepsi seluruh responden tersebut sesuai dengan guideline asma (Global Initiative for Asthma, 2020).

Tujuan pasien dalam pengobatannya juga dipertimbangkan 
Jurnal Ilmiah Ibnu Sina, 6(2), Oktober 2021, 206-214

p-ISSN: 2502-647X; e-ISSN: 2503-1902

dalam menentukan tujuan terapi (Global Initiative for Asthma, 2020) dan persepsi pasien sangat dipertimbangkan sebagai komponen penting dalam menentukan tujuan terapi/ outcome (Bidad et al., 2018; Hannane et al., 2019; Kaptein et al., 2010). Hal ini juga diungkapkan oleh seorang responden yang mengatakan bahwa dalam memberikan pengobatan kepada pasien, beliau memilih untuk tidak memaksakan kehendak pilihan terapi yang menurutnya baik kepada pasien, namun lebih mempertimbangkan keinginan pasien.

\section{Persepsi Pasien Asma Rawat Jalan}

\section{terhadap Pengobatan Asma}

a. Pasien masih belum mengetahui faktor-faktor yang dapat mempengaruhi kesembuhannya terhadap penyakit asma

b. Pasien memiliki inisiatif aktif browsing untuk mencari tahu tentang asma

c. Pasien mengetahui bahwa asma tidak dapat sembuh sehingga menurutnya asalkan tidak asmanya tidak sampai ditingkat yang fatal, ia masih bisa menerimanya

d. Pasien berpendapat bahwa asma tidak bisa disembuhkan hanya dapat dicegah dan dikurangi agar tidak muncul gejala asma, jika muncul gejala maka pasien harus langsung memakai obat

Hasil ini menunjukkan bahwa responden yang merupakan pasien, memiliki wawasan tentang penyakit asma yang cukup baik. Hal ini dapat dilihat antara lain: (1) pasien mengetahui tentang faktor-faktor pemicu asma, (2) pasien mengetahui tentang cara menghindari diri dari kekambuhan asma, (3) pasien mengetahui dengan benar cara menggunakan obat asma, dan (4) pasien mengetahui bahwa penyakit asma merupakan penyakit genetika yang dapat diturunkan. Pasien mengetahui beberapa faktor-faktor yang menjadi pemicu asma antara lain debu, kondisi terlalu dingin dan aktivitas fisik yang berlebihan. Beberapa faktor yang menjadi pemicu asma (trigger) adalah infeksi virus (flu), aktivitas, paparan alergen, perubahan cuaca, tertawa terbahakbahak, asap/debu kendaraan bermotor, asap rokok dan bau yang menyengat (Global Initiative for Asthma, 2020).

$$
\text { Peran farmasis dalam }
$$

penatalaksanaan asma yaitu 
Jurnal Ilmiah Ibnu Sina, 6(2), Oktober 2021, 206-214

p-ISSN: 2502-647X; e-ISSN: 2503-1902

mendeteksi, mencegah dan mengatasi masalah terkait obat yang dapat timbul dari beberapa tahapan seperti (1) rencana pengobatan/care plan, (2) implementasi pengobatan dan (3) monitoring dan evaluasi. Pada tahap implementasi pengobatan terdapat tahapan yang penting yaitu konseling, untuk pasien yang mendapat resep dokter seharusnya saat di apotek oleh farmasis diajukan tiga pertanyaan utama/three prime questions yang dimaksudkan agar (1) membantu pasien rawat jalan untuk memahami rencana pengobatan, (2) tidak terjadi tumpang tindih informasi, perbedaan informasi dan melengkapi informasi yang belum diberikan oleh dokter sesuai kebutuhan, (3) menggali fenomena puncak gunung es dengan memakai pertanyaan-pertanyaan terbuka dan (4) menghemat waktu (Anum et al., 2017; Dalton \& Byrne, 2017; Georgi, 2013; Kritikos et al., 2010).

\section{Persepsi Farmasis terhadap}

\section{Pengobatan Asma}

a. Pengobatan asma menurut apoteker adalah jika pasien rajin kontrol ke dokter dan jika keadaan pasien sudah terkontrol baik, maka akan ada pengurangan kombinasi obat

b. Pengobatan asma selama ini menurut apoteker adalah dengan pasien kontrol rutin ke dokter

Dalam pengobatan asma sendiri, farmasis beranggapan bahwa pengobatan asma pada pasien adalah saat pasien mampu menggunakan obat dengan baik dan adanya penurunan dosis obat akibat tingkat kontrol asma yang membaik pada pasien. Hal ini membuktikan bahwa persepsi farmasis terhadap pengobatan asma juga sesuai dengan guideline pengobatan asma yaitu Global Initiative for Asthma (2020) yang menyebutkan bahwa tingkat kontrol asma merupakan tujuan terapi asma.

Hasil wawancara mengenai persepsi farmasis terhadap peran farmasis dalam pengobatan asma, yaitu:

a. Adanya kerjasama antar tenaga kesehatan sangat dibutuhkan dalam proses pengobatan pasien, dokter meresepkan obat, apoteker menyesuaikan obat dan menjelaskan kepada pasien sampai pasien paham tentang obat yang digunakan selama pengobatannya dan agar pasien tidak salah dalam 
Jurnal Ilmiah Ibnu Sina, 6(2), Oktober 2021, 206-214

p-ISSN: 2502-647X; e-ISSN: 2503-1902

menggunakan obat selama proses pengobatannya

b. Apoteker harus tetap memberikan edukasi kepada pasien meskipun tenaga kesehatan lainnya belum melihat peran tersebut

c. Dokter juga berperan dalam memberikan edukasi kepada pasien, namun jika dokter belum sempat memberikan edukasi, maka menjadi tugas asisten apoteker untuk mengedukasi pasien

Suatu elemen yang esensial dari pelayanan kefarmasian adalah bahwa farmasis menerima tanggung jawab untuk outcome dari terapi obat yang diterima pasien dari tenaga kesehatan lainnya. Komitmen yang sama juga diterapkan untuk mendesain pemberian terapi obat dan rencana pemantauan pasien. Penyediaan layanan kefarmasian memerlukan pemantauan dari efek pemberian obat, penggantian pemberian obat sesuai perubahan kondisi pasien, pendokumentasian hasil dan tanggungjawab terhadap efek pemberian obat (Anum et al., 2017; Georgi, 2013; Kritikos et al., 2010). Berdasarkan teori tersebut, yang didapatkan peneliti adalah peran farmasis sebagai responden sudah sesuai dengan kewajibannya yaitu memberikan edukasi kepada pasien.

Beberapa hal yang dilakukan oleh farmasi komunitas antara lain mengetahui riwayat pengobatan pasien, memberikan konsultasi kepada pasien terhadap pengobatan, mengontrol pengobatan pasien dan memberikan tindak lanjut terhadap pengobatan pasien tersebut (Rockville et al., 2014). Namun berbagai kendala juga dijumpai dalam melakukan penelitian ini terhadap peran farmasis, antara lain adalah (1) kurang munculnya atau kurang dirasakannya peran farmasis dalam pengobatan asma, dan (2) tidak semua pasien mendapatkan edukasi terhadap penggunaan obat asma.

Penyebab dari kedua hal tersebut adalah (1) farmasis selama ini hanya memberikan edukasi kepada pasien yang baru atau (2) farmasis hanya memberikan edukasi penggunaan obat jika ada penggantian obat dan (3) farmasis menganggap bahwa pasien sebelumnya pasti telah mendapatkan edukasi yang baik dari dokter, sehingga farmasis hanya menyerahkan obat saja. Adanya persepsi yang 
Jurnal Ilmiah Ibnu Sina, 6(2), Oktober 2021, 206-214

p-ISSN: 2502-647X; e-ISSN: 2503-1902

muncul dan belum diselaraskan inilah

mampu mengetahui cara

dapat membuat pasien asma tidak

memanajemen asma dan

dapat dengan mudah mencapai tujuan

menggunakan obat asma dengan baik.

dari pengobatannya. Hal ini berbeda

dengan kondisi pelayanan kefarmasian

Hal ini didapatkan dari pengamatan

dan wawancara peneliti dengan

di apotek yang cenderung kurangnya

responden penelitian mulai dari

informasi cara penggunaan inhaler

pada pengobatan asma oleh apoteker kepada pasien asma (Lorensia et al., 2015; Lorensia et al., 2016).

Penelitian oleh Kritikos et al. (2010), pada 75 apoteker di Australia. Apoteker menganggap peran mereka dalam manajemen asma dalam tiga dimensi utama: manajemen diri pasien, penggunaan obat dan pengendalian asma. Sebagian besar apoteker menganggap faktor waktu dan pasien yang terkait menjadi hambatan utama untuk perawatan asma yang optimal dengan kurangnya kepercayaan dan ketrampilan apoteker dalam berbagai aspek perawatan asma penting. Hampir 70\% apoteker menyatakan ingin lebih banyak kontak antar-profesional mengenai perawatan pasien dengan asma.

\section{KESIMPULAN}

Dalam penelitian ini dapat disimpulkan adalah pasien asma telah dokter, pasien, farmasis dan perawat yang menyatakan bahwa pasien dapat memanajemen asmanya dengan baik.

\section{UCAPAN TERIMA KASIH}

Para peneliti mengucapkan terima kasih atas dukungan Hibah LPPM Universitas Surabaya.

\section{DAFTAR PUSTAKA}

Anum, P.O., Anto, B.P., Forson, A.G. (2017) 'Structured pharmaceutical care improves the health-related quality of life of patients with asthma', Journal of Pharmaceutical Policy and Practice, 10(8),pp.19.

Bidad, N., Barnes, N., Griffiths, C., Horne, R. Ratients) 'Understanding patients' perceptions of asthma control: a qualitative study', Eur Respir J, 51(1701346),pp.1-9.

Dalton, K., Byrne, S., (2017) 'Role of the pharmacist in reducing healthcare costs: current insights', Integr Pharm Res Pract, 6,pp.37-46.

George, M., Bender, B., (2019) 'New insights to improve treatment 
Jurnal Ilmiah Ibnu Sina, 6(2), Oktober 2021, 206-214

p-ISSN: 2502-647X; e-ISSN: 2503-1902

adherence in asthma and COPD', Patient Prefer Adherence. 13,pp.1325-34.

Georgi, K. (2013) 'Expanding pharmacists' role in asthma care', PharmacyToday, pp.5153.

Global Initiative for Asthma. (2020). Global Strategy for Asthma Management and Prevention (Update) [online]. Available at: http://ginasthma.org.

Hannane, A., Misane, L., Devouassoux, G., Colin, C., Letrilliart, L., (2019) 'Asthma patients' perception on their care pathway: a qualitative study', NPJ Prim Care Respir Med, 29(1),pp.1-8.

Kaptein, A.A., Klok, T., Moss-Morris, R., Brand, P.L. (2010) 'Illness perceptions: impact on selfmanagement and control in asthma', Current Opinion in Allergy Clinical Immunology, 10(3),pp.194-9.

Kritikos, V. S., Reddel, H. K., BosnicAnticevich, S. Z. (2010) 'Pharmacists' perceptions of their role in asthma management and barriers to the provision of asthma services', International Journal of Pharmacy Practice, 18(4),pp.209-16.

Lorensia, A., Queljoe, D. D., Santosa, K. A. (2015) 'Kelengkapan Informasi Mengenai Cara Penggunaan Peak Flow Meter yang Diberikan kepada Pasien Asma di Apotek', Jurnal Ilmiah Manuntung, 1(2),pp.8-18.
Lorensia, A., Queljoe, D.D., Karina, B.L., Hewu, A. (2016) 'Studi Kelengkapan Penjelasan Cara Penggunaan Sediaan Controller Inhaler (Kombinasi Kortikosteroid Dengan Beta-2 Agonis) Jenis Diskus ${ }^{\circledR}$ dan Turbuhaler® oleh Apoteker di Apotek', Jurnal Ilmiah Manuntung, 2(2),pp.137-46.

Miravitlles, M., Ferrer, J., Baro, E., Lleonart, M., Galera, J., (2013) 'Differences between physician and patient in the perception of symptoms and their severity in COPD', Respiratory Medicine, 107(12),pp.1977-85.

Quirt, J., Hildebrand, K.J., Mazza, J., Noya, F., Kim, H., (2018) 'Asthma', Allergy Asthma Clin Immunol. 14(Suppl 2):5,pp.1630.

Reeves, S., Pelone, F., Harrison, R., Goldman, J., Zwarenstein, M., (2017) 'Interprofessional collaboration to improve professional practice and healthcare outcomes', Cochrane Database Syst Rev, 6(6):CD000072.

Rockville, W., Franklin, M., Sorra, J. (2014) 'Community Pharmacy Survey on Patient Safety Culture: User's Guide', AHRQ Publication, 12(13) ,pp.0085.

Smith, J.A., Osborn, M., (2015) 'Interpretative phenomenological analysis as a useful methodology for research on the lived experience of pain', Br J Pain, 9(1),pp.41-42. 